\title{
РОЗВИТОК НОВИХ ТЕХНОЛОГІЙ У ПІСЛЯДИПЛОМНІЙ ОСВІТІ ЛІКАРІВ І ПРОВІЗОРІВ: ТЕНДЕНЦЇ̈, ЕКСПЕРТНІ ВИСНОВКИ ТА РЕАЛЬНІ ОЦІНКИ ЕФЕКТИВНОСТІ НАВЧАННЯ
}

\author{
Наџіональна медична академія післядипломноїосвіти імені П. Л. Шупика
}

\section{DEVELOPMENT OF NEW TECHNOLOGIES IN POST-GRADUATE EDUCATION OF DOCTORS AND PHARMACISTS: TENDENCIES, EXPERT CONCLUSIONS AND REAL ESTIMATIONS OF STUDIES EFFICIENCY}

\author{
Yu. V. Voronenko, O. P. Mintser \\ National Medical Academy of Post-Graduate Education by P. L. Shupyk
}

\begin{abstract}
Розглянуті особливості переходу системи освіти від індустріальної до постіндустріальної моделі (інформаційного суспільства). Аналізуються експертні висновки про ризики технологічної й інформаційної сингулярності. Наведені особливості дистанційної та інших технологій у післядипломній медичній освіті.
\end{abstract}

The peculiarities of transition of the system of education from industrial to post-industrial model (informational society) are considered. Expert conclusions about the risks of technological and informative singularity are analysed. The special features of distance and other technologies in post-graduate medical education are given.

Вступ. Сьогодні освіта переживає перехід від індустріальної моделі до постіндустріальної, до так званого інформаційного суспільства. На всіх ділянках цієї глобальної трансформації в освіті виникає ряд суперечливих процесів. Їх масштаб настільки великий, що порівняти їх можна, мабуть, із періодом виникнення писемності.

Експоненціальне прискорення технічного прогресу основна особливість XXI століття. Зміни, що ми бачимо, обумовлені трьома основними чинниками: масовий прогрес у технологіях, діяльність на стику різних дисциплін і злиття галузей (розмивання меж між ними). В результаті, за загальною експертною думкою, людство знаходиться на межі змін, порівнянних із появою на Землі людини.

Так, 2012 рік увійде до історії як рік завершення ери панування персональних комп'ютерів (ПК), здійснюється глобальна ставка на різноманіття інтелектуальних пристроїв: мобільні телефони, планшети та телевізори, що стають популярними, із вбудованою операційною системою нестримно витісняють комп'ютери з лідируючих позицій. Замість жорсткого диска настільного комп'ютера з'явилися “хмарні” сховища даних, завантаження додатків із Apple Store, а не зі сумнівних сайтів тощо.

Злиття реального та віртуального світу найближчими роками спричинить такі зміни, що переоцінити важливість нових технологій просто неможливо. Слід лише назвати появу замість телевізорів і ПК запропонованих окулярів доповненої реальності (зокрема, окуляри Google Glasses), численні дисплеї з комп'ютерними функціями. В 2013 році автомобіль Google Сar офіційно зареєстровано як перший транспортний засіб, якому дозволено переміщатися по звичайних дорогах без участі людини, агентство США з перспективних оборонних дослідницьких розробок (Defense Advanced Research Projects Agency, DARPA) представило робота Cheetah, здатного бігати зі швидкістю 45 км на годину, тобто швидше за будь-яку людину.

Експоненціальний прогрес у галузі біології ще очевидніший при розгляді проектів розшифровки людського геному. У повсякденну практику лікаря приходять нові високі технології, що вимагають для їх ефективного використання нових знань і навичок, арсенал лікарських засобів обчислюється тисячами.

(C) Ю. В. Вороненко, О. П. Мінцер 
Останнім часом поширення отримав термін “технологічна сингулярність". Найбільш радикальне уявлення про технологічну сингулярність припускає, що насправді вона означає нескінченне зростання технологій за кінцевий час. Отже, він визначає момент у часі, коли технічний прогрес стане настільки швидким $\mathrm{i}$ складним, що виявиться недоступним розумінню.

За ним, ймовірно, йдуть створення штучного інтелекту та машин, котрі самі відтворюються, інтеграція людини $з$ обчислювальними машинами, або значне стрибкоподібне збільшення можливостей людського мозку за рахунок біотехнології. Термін “"технологічна сингулярність" поступово завойовує визнання. Згідно 3 думкою окремих дослідників, технологічна сингулярність може настати вже близько 2030 року. Проте ще раніше може настати інформаційна сингулярність.

Під інформаційною сингулярністю зазвичай розуміється відрізок часу, коли інформаційний обсяг, що множиться в геометричній прогресії, набуває лавиноподібного зростання. Вже зараз Інтернет - це гіпермедійне середовище, в якому забезпечено швидкий доступ до величезного обсягу мультимедійної інформації. При цьому виникають загрози знищення критеріїв достовірності і якості інформації, що може призвести до колапсу інфосфери та знищення знань як таких. Відмітимо, що, наприклад, кількість медичних журналів, котрі сьогодні видаються, перевищує 2000.

Усе сказане примушує по-новому розглядати проблеми освіти.

Основна частина. Загальні зауваження. Очевидно, нова освіта повинна орієнтуватися на можливості надшвидкісного доступу до інформації Інтернет-гіпермедійного середовища. Передусім, зникає необхідність зберігання та запам'ятовування медичних даних і знань. Для цього можливе використання всього інформаційного інструментарію від комп'ютерів до комп'ютерних мереж, у тому числі, природно, й Інтернету.

Акцент навчання повинен зміститися в бік прискорення оброблення інформації, від заучування безлічі фактів і технологій, що стало непотрібним, до навчання когнітивних методик: пошуку, систематизації, аналізу, зіставлення, узагальнення та синтезу нових знань. Тобто для переходу до суспільства знань необхідно створити таку систему освіти, де в масовому порядку викладатимуться когнітивні навички, якими раніше володіли тільки професійні дослідники. Можна сказати, що масовими повинні стати метатехнології освіти, коли кожна освічена людина володіє методиками, технікою та навичками - дослідження, аналізу, синтезу. Підкреслимо, що це найважливі- ший якісний перехід у системі освіти, особливо післядипломної. Якщо в існуючій індустріальній моделі освіти “точка збору” навчальної інформації в тій або іншій дисципліні здійснюється викладачем, то в новій освіті середній фахівець повинен сам уміти знайти, створити цю точку збирання в тій сфері, у якій він в даний момент працює.

У медичній галузі необхідність змінення існуючої системи освіти додатково підсилюється багатьма чинниками: винятковим збільшенням обсягів знань; швидкою зміною самого розуміння подій, фактів, явищ; забезпеченням вільної індивідуальної освітньої траєкторії, впровадженням моделі компетенцій тощо. Більше того, в сучасній післядипломній медичній освіті мають бути створені такі технології навчання, що дозволять готувати масово фахівців із дослідницькими навичками.

Відходять у минуле технології використання баз даних безпосередньо в комп'ютерах. Замість них застосовується розміщення контенту в хмарних технологіях. Проте розміщення медичного контенту в базах знань позбавляє медичну освіту, особливо післядипломну, частини фінансової привабливості.

Стає очевидним, що сучасному лікареві вже недостатньо знань, засвоєних на студентській лаві, знань, отриманих в ординатурі або аспірантурі. Підготовка лікаря має бути безперервною. Важливо підкреслити, що нинішня освітня стратегія ігнорує зростаючу складність світу. Рідко хто враховує, що "роками перевірені методи" сьогодні не лише не дають результат, але, навпаки, призводять до негативних результатів (досить згадати історію з АЕС Фукусіма-1, при якій складність контрольованої системи виявилася надмірною для людини). Отже, слід навчати лікарів і провізорів таких моделей мислення, що дозволять не загубитися в потоці інформації, контролювати цю складність, що збільшується.

Технології передавання знань у післядипломній освіті. Нинізапропонована великакількість нових, ефективних методів навчання. Головна їх особливість - навчання лікарів особово-орієнтованого підходу з формуванням уміння визначати переваги пацієнта, консультувати його без утиску права на незалежність i самостійність, здатність вирішувати певні проблеми пацієнта через відбір та оцінку інформації при зборі анамнезу, обстеженні, вміння приймати рішення в невідкладних ситуаціях, проводити ранню діагностику на початкових, недиференційованих стадіях захворювання, раціонально призначати діагностичні та лікувальні втручання. Все це складає групу компетентністних вимог, що пред'являються до сучасного спеціаліста. 
Особово-орієнтовані технології забезпечують дидактичні технології (технології проблемного навчання, модульного навчання, технології індивідуалізації навчання тощо), при яких досягається засвоєння знань, умінь, формування навичок. Головним завданням навчання лікарів є формування клінічного креативного мислення.

Для уточнення перспектив конструктивної педагогіки важливо вказати на наявність зв'язків проблемного навчання 3 інтегрованим навчанням, що $€$ підсистемою загального навчання, в якому навчальний процес складається з групи взаємопов' язаних, цілеспрямованих комплексів, різних видів навчання, що мають навчальну, наукову, професійну єдність. Сенс інтегрованого навчання полягає в досягненні максимальної оптимізації при підготовці фахівців вищої кваліфікації з урахуванням прогнозованого розвитку науки та практики у відповідній сфері діяльності. Науково-дослідна робота є видом проблемного навчання. В процесі наукової роботи виявляються схильності суб' єктів навчання до цілеспрямованої діяльності, формується система навичок для творчого пошуку. Важливим компонентом у використанні інтенсивного методу є гнучкість і можлива перебудова викладу навчального матеріалу.

Дистаниійне навчання. Одна з нових технологій, що нестримно набирає швидкості впровадження, дистанційне навчання. Воно стало реальністю, незважаючи на тривалу критику з боку значної частки старшого покоління лікарів. Найбільшу прихильність до такого способу отримання/оновлення знань відчувають висококваліфіковані фахівці, що цінують час і проявляють самодостатність.

Існують дві групи чинників, що формують контингент лікарів (провізорів), які прагнуть до дистанційного навчання. Перша - узагальнює потребу фахівців спілкуватися на основі сучасних комунікативних засобів із викладачем, своїми колегами, які паралельно вивчають цей курс і розуміють необхідність дистанційних консультацій із експертом з даного питання.

Друга група визначає можливість самостійно контролювати процес навчання, самостійно планувати свою освітню активність, не потребуючи постійної опіки. Це властиво більшою мірою зрілим професіоналам. Фахівець цінує можливість свободи вибору змісту, форм представлення та рівня складності навчального матеріалу. Він краще обирає власну освітню траєкторію. При цьому важливе отримання вільного повноцінного доступу до великих джерел інформації в Інтернеті або інших мережах, використовуваних для навчання.
Підкреслимо, що дистанційне навчання лікарів i провізорів є складною, добре регульованою та контрольованою системою. Спроби вибіркового використання окремих методів, фрагментів і навіть технологій дистанційного навчання не можуть привести до якісного підвищення освітнього рівня контингентів, які залучаються до навчання.

Наприклад, дуже поширену сьогодні технологію використання журналів із розміщенням питань для дистанційного контролю знань і реалізації накопичувальної системи балів при безперервному професійному розвитку (БПР) можна та необхідно застосовувати, але лише в комплексі з іншими підходами, що забезпечують системність передавання знань.

Така технологія, що виконується у тому числі онлайн, обмежена в коректній ідентифікації суб'єкта навчання, не забезпечує моніторингу й оцінювання виживаності знань.

Видається важливим обговорення проблеми тривалого прикріплення суб' єкта навчання до кафедри, що здійснює післядипломне навчання, і забезпечення відповідальності кафедри за якість навчання. Одним із важливих механізмів, що забезпечують коректність процедур освіти, є створення портфоліо (індивідуальної бази даних) суб' єкта навчання.

Загальноприйнято, що для високої якості дистанційного навчання необхідно забезпечити: ясну й об'єктивну систему оцінок пропонованих тестів; пояснення й обгрунтування оцінювання знань; розуміння суб' єктами навчання значення оцінок і того, чи є прогрес, навіть якщо оцінки залишаються незмінними.

Основне завдання, що ставиться при проведенні дистанційного навчання, - максимальне наближення “віртуального” навчання до реального (безпосереднього). Часто застосовуються кейс-технології, при яких відбувається передавання слухачеві заздалегідь підготовленого, записаного, змонтованого матеріалу для самостійного вивчення; відеоконференцзв'язок реалізується як на базі загальновідомих програм при проведенні індивідуального навчання, так і спеціалізованого програмно-апаратного забезпечення при проведенні групового навчання. Також використовуються програмні комплекси для створення вебінарів і віртуальних кімнат за наявності групи слухачів, що збігаються за часом, але віддалених у просторі. Застосовуються також опорні конспекти лекцій, комп'ютерні анімовані презентації лекцій, рубіжний контроль та інші методи.

Аналізуючи сучасний стан дистанційного медичного навчання, можна резюмувати, що існуючі в Україні спроби використання елементів дистанційного 
навчання швидше є декларативними, ніж ефективними, щодо підвищення якості післядипломної освіти. Водночас застосування дистанційних семінарів, журнальних публікацій із елементами контролю знань, медичних порталів є початковим елементом дистанційної системи післядипломної освіти, поки не представленої у своєму цілісному раціональному вигляді.

Формалізація та структуризація контенту післядипломної медичної освіти є найважливішою проблемою сучасної післядипломної освіти. Однією 3 перспективних технологій слід визнати розроблення методів формалізації професійних знань лікаря (провізора) на основі інтелектуальних технологій. У них важливим $є$ ідентифікація стану здоров'я пацієнта та вибору тактики лікування.

Останні, у свою чергу, вимагають вирішення таких завдань: сформувати структуру інформаційного забезпечення інтелектуальних технологій ідентифікації в завданнях медичної діагностики та вибору тактики лікування на основі алгоритмізації оцінювання інформативності лабораторних показників i клінічних симптомів; запропонувати методику формалізації початкової нечіткої інформації в термінах лінгвістичних змінних і формування правил виведення в загальній структурі інформаційного забезпечення; розробити алгоритм формування регресійних моделей для опису процесу перебігу захворювань на основі підбору лінеаризуючих перетворень; побудувати комплекс регресійних моделей динаміки фізіологічних показників і запропонувати оптимізаційну процедуру вибору тактики лікування.

Самоосвіта ц̆ отримання знань в Інтернетбібліотеках. Звичайні книгосховища орієнтовані, як правило, на популярні видання. А вузькоспеціалізовані бібліотеки при академіях і університетах, на жаль, не завжди зручно розташовані, та і формальності, яких слід дотримуватися при отриманні необхідної літератури, пов’язані з втратами часу та сил.

Альтернативою можуть бути бібліотеки в Інтернеті, що дозволяє займатися в слушний для фахівця час $\mathrm{i}$ спланувати процес самонавчання. Якщо ж цей ресурс організований як корпоративний із комп'ютерною реалізацією пошуку необхідної інформації, зручною системою рубрикації, то реально створюються умови для збільшення часу, впродовж якого фахівець зможе навчатися. Важливо підкреслити, що оперативність i актуальність є необхідними умовами успішності самонавчання. Інтернет-корпоративна бібліотека всі зазначені переваги надає в повному обсязі: зручність пошуку, вільний вибір місця та часу для занять, валідна інформація, зручний і великий каталог.
Контроль знань. У широкому розумінні якість вищої освіти являє собою збалансовану відповідність вищої освіти різноманітним потребам, цілям, вимогам, нормам, еталонам, стандартам. Уся європейська система вищої освіти постійно працює над підвищенням якості підготовки фахівців. У рамках болонських реформ виробляються єдині підходи до забезпечення якості вищої освіти, до розроблення навчальних матеріалів. Відбувається до деякої міри уніфікація вищої освіти та їі ступенів, хоча філософія Болонського процесу будується на визнанні та збереженні національних культурно-освітніх традицій.

Сьогодні контроль знань представляє вертикаль тестових процедур. Важливо підкреслити, що ні сама процедура контролю, ні сам підхід не відповідають сучасним вимогам. Замість лінеаризованого правила оцінювання знань повинен прийти багатовимірний контроль, замість одноразового виміру рівня знань постійний їх вимір і реєстрація в портфоліо для швидкої та адекватної корекції освіти.

Важлива реалізація підходу, грунтованого на підтримці та дружелюбності (викладач завжди має знаходиться на стороні суб' єктів навчання); необхідні змістовні та доброзичливі за формою коментарі; забезпечення конструктивних порад (прямі посилання на матеріал курсу та вказівки, де знаходиться той матеріал, що суб'єкти навчання пропустили або недостатньо розуміли і так далі); наявність стимулів до подальшого просування; відсутність складних, заплутаних або незрозумілих відповідей із боку викладача; можливість у разі необхідності особистої взаємодії з викладачем; швидкий відгук. Перерахований комплекс дій повинен реалізовуватися як у режимі самонавчання, так і шляхом взаємодії викладача та суб'єктів навчання в реальному масштабі часу.

Також важливою є інтеграція наявних сил і засобів для формування системи індивідуального дистанційного навчання з об'єктивною персоналізацією слухачів і контролю їх знань. Поза сумнівом, і те, що кафедра як інтегратор знань визначає індивідуальну стратегію навчання та дозволяє слухачеві обрати куратора (наставника) свого освітнього процесу.

Розглядаючи стратегію розвитку післядипломної медичної освіти в умовах нових викликів (загроз технологічної й інформаційної сингулярності), необхідно постійно модернізувати всі складові освітнього процесу, а саме: власне процедури навчання, структуризацію знань, технології доставки знань у процесі навчання; контроль знань.

Висновки: 1. Одним із шляхів попередження інформаційної сингулярності в післядипломній ме- 
дичній освіті є підготовка фахівців із когнітивними навичками, які вміють обробляти, класифікувати, узагальнювати та створювати нове знання з великого потоку різнорідних фактів.

2. Найважливішою проблемою сучасної післядипломної освіти є формалізація та структуризація контенту навчання.

3. Невід'ємними частинами безперервного профе-

\section{Література}

1. Аблязов Н. Технологическая сингулярность. Исследование предпосылок возникновения и последствий для человечества / Н. Аблязов. - Режим доступа: http:// philosophy.mipt.ru/f_1vsglb/f_1vsgxk/a_1xes5v.html.

2. Васюгова С. А. Информационное общество: следование перспектив и проблем интеграции человека с компьютером. Технологическая сингулярность как новый этап обучения в образовании / С. А. Васюгова, О. О. Варламов. - Режим доступа: http://info-alt.ru/2011-09-05-07-56-07.

3. Грудзинский А. О. Управление качеством образования: опыт Нижегородского университета / А. О. Грудзинский, А. В. Петров, М. Ю. Щербань // Вестник Российского университета Дружбы народов. Серия “Информатизация сійного розвитку лікарів і провізорів повинні стати: дистанційне навчання, самоосвіта та корпоративна Інтернет-бібліотека.

4. Серед проблем, що вимагають швидкого обговорення, слід виділити, тривале прикріплення суб'єкта навчання до кафедри, що здійснює післядипломне навчання, і забезпечення відповідальності кафедри за якість навчання.

образования”. -2005. - № 19(2). - С. 99-107.

4. Грудзинский А. О. Европейский трансфер технологий: кооперация без утечки мозгов / А. О. Грудзинский, Е. С. Балабанова, О. А. Пекушкина // Социологические исследования. -2004. - № 11.-С. 123-131.

5. Селезнева Н. А. Качество высшего образования как объект системного исследования : лекция-доклад / Н. А. Селезнева. - М. : Исследовательский центр проблем качества подготовки специалистов, 2001.-79 с.

6. Стронгин Р. Г. Университет как интегратор в обществе, основанном на знании / Р. Г. Стронгин, Г. А. Максимов, А. О. Грудзинский // Высшее образование в России. - 2006. -№ 1.-C. 15-27. 